\title{
"Let Mrs Mafekeng stay": An evaluation of the Paarl riots of 1959
}

\section{Amy Rommelspacher*}

\begin{abstract}
In South African historical research, the Paarl riots of 9-10 November 1959 have been viewed fleetingly as an episode centred around Elizabeth Mafekeng, ${ }^{1}$ a trade union activist of the 1940s and 1950s. On closer examination, however, most of the participants in the events, Coloured people, ${ }^{2}$ seem to have drawn to them for multifaceted reasons which question assigning their cause to the banishment of Mafekeng alone. The Cape Times, Cape Argus, New Age, Die Burger and Paarl Post newspapers were examined for information concerning the riots. The Paarl Magistrate's Criminal Records also provided insight into the nature of the unrest, while secondary literature concerning the Coloured population was also studied. The basis of the involvement of local inhabitants in the events was found to have been divided. Their participation could not be pinned down to one person or a single cause. Instead, a depiction and investigation of the full account of the events reveals three main groups that could be identified within their collective body. There were those who were actively involved; those who consciously separated themselves from the proceedings; and those whose participation did not seem to be politically motivated. The events appear to be more complex than they have been remembered.
\end{abstract}

Key words: Elizabeth Mafekeng; Paarl; protest; African National Congress (ANC); apartheid.

* Amy Rommelspacher is working towards her MA in History at Stellenbosch University, focusing on the South African housewife in the first half of the twentieth century. While completing her BEd and Honours degree in History, she became interested in women's history; the home, public health, food and cookery, education and community.

1. The quote in the title is taken from the newspaper article, "Rioting Mob Smashed Cars", Paarl Post, 10 November 1959, p 10.

2. Mohamed Adhikari explains that the use of the term "Coloured" is complicated, even in post-apartheid South Africa. He prefers to use a capital "C" whether the word is used as an adjective or not. At the time of the riots discussed in this article, the term Coloured was used by the apartheid government to describe those who were neither defined as Asian, "Bantu” or "White". See M. Adhikari, Not White Enough Not Black Enough (Double Storey Books, Cape Town, 2005), pp xiv, v. In this article the terms used are Coloured, African and white. However, in direct quotations of the time there are different forms and these will obviously be retained. See Republic of South Africa (hereafter RSA) Bureau of Statistics, Population Census, Volume 1, 6 September 1960, Geographical Distribution of the Population (Government Printer, Pretoria, 1961), p iii.

How to cite this article: A. Rommelspacher, "'Let Mrs Mafekeng stay': An evaluation of the Paarl riots of 1959", Historia, 62, 1, May 2017, pp 48-72.

http://dx.doi.org/10.17159/2309-8392/2017/v62n1a3

Copyright: (CThe Author(s). Published under a Creative Commons Attribution Licence. 


\section{Opsomming}

In Suid-Afrikaanse historiese navorsing, is die Paarl onluste van 9-10 November 1959 vlugtig gesien as 'n episode gesentreer rondom Elizabeth Mafekeng, 'n vakbond-aktivis van die 1940's en 1950's. Met nadere ondersoek, het die meeste van die deelnemers, Kleurling mense, vir veelsydige redes in die gebeurtenisse betrokke geraak. Dit begin om dus te bevraagteken of die verbanning van Mafekeng alleen hulle na die onluste getrek het. Die Cape Times, Cape Argus, New Age, Die Burger en Paarl Post koerante is vir inligting oor die onluste ondersoek. Die Paarl-landdroshof Kriminele Rekords verskaf insig in die aard van die onrus, terwyl sekondêre literatuur, met betrekking tot die Kleurlingbevolking ook bestudeer is. Die basis van die betrokkenheid van plaaslike inwoners in die gebeure is gevind om van 'n gedeelde aard te gewees het. Hul deelname kon nie vasgepen wees aan een persoon of 'n enkele oorsaak nie. In plaas daarvan, gee 'n uitbeelding en ondersoek van die volle rekening van die gebeure tekens van drie hoofgroepe, wat geïdentifiseer kan word binne hul kollektiewe liggaam. Daar was diegene wat aktief betrokke was; diegene wat hulself doelbewus geskei het van die gebeurtenisse; en diegene wie se deelname nie polities gemotiveer gelyk het nie. Die gebeure blyk meer kompleks as wat dit onthou is.

Sleutelwoorde: Elizabeth Mafekeng; Paarl; protes; African National Congress (ANC); apartheid.

\section{Introduction}

In November 1959, Paarl, a town in the Western Cape, South Africa, was thrust into the national and international limelight when two days of unrest broke out in its midst. These events have been predominantly, and fleetingly, portrayed as a unified reaction to the banishment of the politically prominent African Food and Canning Workers' Union leader, Elizabeth Mafekeng, in October of that year.

The Poqo riot of 1962 has drawn most of the academic attention to unrest in Paarl, ${ }^{3}$ potentially because of the contemporaneous attention it garnered as a violent attack on white people by Africans. Yet, journalist Myrna Blumberg claimed that the Paarl riot of 1959 was the first sizeable reaction to apartheid in the Western Cape. ${ }^{4}$ She provocatively proposed that the Mafekeng affair served as a catalyst to existing unease, and she continued to make Elizabeth Mafekeng the central figure in her account of the events. Existing brief accounts of the 1959 unrest suggest exclusively organised resistance by the ANC, the PAC or other anti-apartheid movements with a central mythologised figure - Elizabeth Mafekeng - as their nature and cause. But in remembrance of the incident the thousands who participated have been overlooked.

3. Poqo was the name of the military wing of the Pan Africanist Congress (PAC). It was synonymous with violence and anti-white politics. See RSA, Commission Appointed to Inquire into Events on 20th-22nd November 1962 at Paarl and the Causes that Gave Rise thereto (Government Printer, Pretoria, 1963), pp 3 -5.

4. M. Blumberg, "The Mafekeng Affair”, Africa South, 4, 3 (April/June 1960), p 39. 
This article strives firstly, to provide a detailed account of the context and events of 9-10 November 1959 in Paarl. Secondly, the accounts are utilised to reveal the specific groups that were involved in the riots in order to determine whether or not the upheavals were exclusively characterised by homogenous heroic struggle for Mafekeng's cause.

\section{PART 1}

Historians Tom Lodge and Bianca van Laun have presented works on different aspects of the Poqo Riot of 22 November 1962 in Paarl, an incident marked by violence which resulted in the death of two young white members of the Paarl community. ${ }^{5}$ The 1959 upheavals were viewed as events which contributed to the political environment which gave rise to the much publicised 1962 riot. $^{6}$ In their references to 1959 , both view Elizabeth "Mafikeng" (sic) as its cause.7 The South African correspondent to the New York Post and the London Daily Herald at the time of the riot, Myrna Blumberg, ${ }^{8}$ did the same in her article The Mafekeng Affair (1960). ${ }^{9}$ The Food and Allied Workers' Union (FAWU) website relays that this trade union: "together with the ANC, the Congress of Democrats, the Coloured People's Congress, SACTU and the Women's Federation, ... organized a demonstration in protest against the banishment by guarding her house day and night."10 The FAWU and South African History Association websites all have similar accounts further colouring the remembrance of the events. ${ }^{11}$

5. T. Lodge, "The Paarl Insurrection: A South African Uprising”, African Studies Review, 25, 4 (December 1982), pp 95.

6. Lodge, "The Paarl Insurrection", pp 99, 114. See also B. van Laun, "In the Shadows of the Archives: Investigating the Paarl March of 22 November 1962", MA dissertation, University of the Western Cape, 2012, p 111.

7. There is confusion on the spelling of Elizabeth Mafekeng's surname in Lodge and Van Laun's work as well as elsewhere. "Mafekeng" is considered to be the name she went by, though Lodge and Van Laun refer to her as "Mafikeng".

8. J. Nix, Freedom of Expression Institute, "Actions against Journalists in SA between 1960 and 1994", May 1997 <http://www.fxi.org.za/old\%20webpages/archives/DUMP/text \%20files/detention.txt> (Accessed 8 October 2015). See also http://hansard. millbanksystems.com/commons/1960/apr/12/union-of-south-africa-miss-myrnablumberg (Accessed 8 October 2015).

9. Blumberg, "The Mafekeng Affair", p 41.

10. "Elizabeth Mafikeng" (sic), at http://www.fwu.org.za/index.php?include=veterans /mafikeng.html (Accessed 24 August 2015).

11. The Food and Allied Workers' Union was formed in 1941 as the African Food and Canning Worker's Union (AFCWU). This name is given in the literature studied and will be used in this article. See http://www.fawu.org.za/show.php?ID=222 (Accessed 24 August 2015). T. Karis and G.M. Gerhart (eds), From Protest to Challenge: $A$ Documentary History of African Politics in South Africa, 1882-1964, Volume 3, Challenge and Violence, 1953-1964 (Hoover Institution Press, Stanford, 1977) provides a political profile of Mafekeng of one paragraph, which generally echoes the websites. There is also a small section on her in Human Sciences Research Council, Women Marching into the 21st Century: Wathint' Abafazi, Wathint' Imbokodo (HSRC Press, Cape Town, 2000). 
The existing secondary literature has sculpted the happenings in 1959 in Paarl as organised rioting which revolved around a central figure under the influence of formal political institutions. This may be a valid contemporary explanation, but one particular aspect of the unrest introduced by Blumberg in her critique of the state's explanation suggests nuances to involvement in the unrest:

... it must be said at once that simply blaming the events at Paarl on hooligans or agitators does not by any means explain the deeper reasons for what happened or relieve the Government of its culpability in the matter. ${ }^{12}$

This quote introduces the idea that at the time of the unrest, "hooligans or agitators" were seen to be culpable by the state. The perception of those involved as "hooligans" is a contrast to the observations in secondary literature, which portray the incident solely as organised anti-apartheid protest.

Elizabeth Mafekeng's impact on the events of 1959 is undeniable. Born in 1918 in a small Karoo town called Tarkastad, she moved to Paarl in 1927.13 For 22 years she lived in the same suburb in that town with her husband, Moffat Mdgatane and 11 children. She was a politically impressive figure entering a life of activism after joining the African Food and Canning Workers' Union (AFCWU) in the 1940s. In 1954 she was elected as its president. ${ }^{14}$ She was a committee member of the National Executive of the Federation of South African Women (FEDSAW); became vice-president of the African National Congress (ANC) Women's League in 1957 and participated in the 1952 ANC-led defiance campaign. In 1955 she visited England and various communist countries. ${ }^{15}$ Throughout the 1950s, ANC members visited conferences around the

All are scarcely referenced and provide a rough outline of her political career although only two refer briefly to the riot of 1959. S. Badat, Forgotten People: Political Banishment under Apartheid (Jacana Johannesburg, 2012) refers to the life of Mrs Mafekeng and makes extensive use of the article by Blumberg mentioned above.

12. Blumberg, "The Mafekeng Affair", p 44. The police chief, Colonel Terblanche, also blames the riots on "hooligans". This idea will be discussed further below. See "Police Chief Blames Coloured Hooligans for Rioting at Paarl", The Cape Argus, 10 November 1959, p 1.

13. “'Mr Mafekeng' says: I will Not be Dumped in Bush", Cape Times, 16 November 1959, p 3. It seems she moved to Paarl in 1927, but no reliable sources could be found. for this information. This date was found on the FAWU website but other information there has proved to be incorrect. See http://www.fawu.org.za/index.php?include=veterans/ mafikeng.html (Accessed 1 July 2015); and Karis and Gerhart (eds), From Protest to Challenge, Volume 3, p 64.

14. See "Elizabeth Mafikeng" (sic) in the FAWU website http://www.fawu.org.za/index. php?include=veterans/mafikeng.html (Accessed 1 July 2015).

15. “'Mr Mafekeng' says: I will Not be Dumped in Bush", Cape Times, 16 November 1959, p 3; "Mrs Mafekeng's Visit to Red Countries", Cape Times, 11 November 1959, p 6; and C. Gurney, "'A Great Cause': The Origins of the Anti-Apartheid Movement, June 1959March 1960", Journal of Southern African Studies, 26, 1 (March 2000), pp 126-144. 
world to muster support for the boycott of South African produced goods. ${ }^{16}$ Mafekeng also partook in various events protesting against pass books for African women in 1956; and another in Paarl in October 1959.17 Her banishment was issued by De Wet Nel, minister of Bantu Administration and Development, on 12 October 1959.18 She was required to leave Paarl by 2 November, but was later given a week's extension. ${ }^{19}$

As well as being an iconic political figure, or perhaps because of it, she was considered a threat to state security:

According to Mr Daan [de Wet] Nel, Minister of Bantu Administration, Elizabeth Mafekeng said at her trade union meetings that the non-whites should gain their freedom with blood, guns, knives and rocks.

She was also quoted as saying that people in China were unable to gain their freedom by constitutional means, but [did so] with blood.

The request to have her removed came from the Paarl Town Council.20

It becomes clear why Elizabeth Mafekeng became synonymous with the Paarl unrest of 1959. She was a key figure in the events of 9 to 10 November and furthermore, was a resident of Paarl; her position of belonging in that community would undoubtedly have led to support against her banishment from those with whom she had lived for over 20 years. ${ }^{21}$ Although the nature of her participation on those nights has been lost in the existing literature on the riots in Paarl, Mrs Mafekeng has certainly been placed at the centre of events. The incidents at Paarl show more complex forces at play and reveal multiple forms of involvement. ${ }^{22}$

16. Gurney, “'A Great Cause”, pp 126-144.

17. "Mrs Mafekeng's Visit to Red Countries", Cape Times, 11 November 1959, p 6; Blumberg, "The Mafekeng Affair", p 41.

18. Blumberg, "The Mafekeng Affair", pp 40-41.

19. "Black Sash Protest", Cape Argus, 2 November 1959, p 3.

20. Own translation from the article, "Waarom Mafekeng Verban is", Paarl Post, 26 January 1960, p 1.

21. C.J.P. Fransch, “'We would have no name': The Porosity of Locational and Racial Identities amongst the 'Coloured Communities' of Stellenbosch c. 1890-1960s", African Studies, 69, 3 (December 2010), pp 403-422.

22. Five varied media sources have been consulted to reconstruct the events of 9-10 November 1959. Each of the newspapers consulted had a specific readership and political slant at the time. Die Burger was considered the mouthpiece of the National Party (NP), while the New Age was the voice of those who opposed apartheid. The Cape Times and Cape Argus were both English newspapers with liberal tendencies. During the 1950s, the Cape Times became known for openly denouncing apartheid. The Paarl Post was a small newspaper of no obvious alliances, but on analysis it seems to have had a tendency to express NP sentiment. See G. Shaw, The Cape Times: An Informal History (New Africa Books, Cape Town, 1999) pp 83, 155, 257. 
On 9 November 1959, in the suburb of Huguenot, Paarl, people congregated outside the home of Mrs Elizabeth Mafekeng. ${ }^{23}$ They had been gathering along the street since the previous week in anticipation of her removal. ${ }^{24}$ Most of those in the crowd were Coloured people. ${ }^{25}$ According to Blumberg, delegates from Paarl and other Cape branches of the African Food and Canning Workers Union (AFCWU) arrived too. ${ }^{26}$ Some in the crowd were holding signs that read "Let Mrs Mafekeng Stay". ${ }^{27}$ As darkness fell the crowd increased to 3000 and the atmosphere became aggressive. Weapons such as bush knives, sticks and lengths of iron were produced. The crowd began to turn to violence at around 20:00 when people began throwing objects at passing cars. A group of women chanted "kill them, kill them!" while others shouted: "Afrika! Afrika!". ${ }^{28}$ Two white men were hospitalised after their car was overturned and set alight. Both were beaten and stabbed, but neither sustained fatal injuries. A Coloured taxi driver, a Mr G. de Vos, was attempting to drive through the crowd when he was stopped by the throng. Initially he was allowed to pass because he was Coloured, but a few metres on he was stopped again, pulled out of his car and beaten with sticks. He sustained head injuries. ${ }^{29}$ It appears that all who were not involved in the riots were targeted. For example, the car of a Mr D.J. Cupido, a well-known member of the Coloured community, was also attacked. ${ }^{30}$ A commercial traveller, a Mr Poggi of Tamboerskloof, hit at least two Africans with his car as he tried to flee the crowd. ${ }^{31}$ According to the New Age, some rioters compelled motorists to give the "Afrika!" salute. If the salute was given, those stopped were allowed to pass, if not, they were dragged from their cars and subjected to violence. ${ }^{32}$

Those rioting were heard calling out: "If they come to take Mrs Mafekeng, they will take her over our dead bodies"; "Kill Verwoerd, kill De Wet Nel, kill the police"; and "Keep out of the way because blood will flow tonight". Hendrik Verwoerd was the prime minister of the Union of South Africa at the time, before which he had been the

23. "Police Chief Blames Coloured Hooligans for Rioting at Paarl", The Cape Argus, 10 November 1959, p 1; "Police Fire in Battle with Paarl Rioters: Screaming Mob Stone Cars, Attack Occupants”, The Cape Times, 10 November 1959, p 1.

24. “Nie-Blanke Geweld in die Paarl: Aanrandings, Brande", Die Burger, 10 November 1959, $\mathrm{p} 1$.

25. “Min. Nel se Verklaring oor die Onluste”, Die Burger, 13 November 1959, p 8.

26. Blumberg: "The Mafekeng Affair", p 42.

27. “Rioting Mob Smashed Cars", Paarl Post, 10 November 1959, p 10.

28. "Police Chief Blames Coloured Hooligans for Rioting at Paarl", The Cape Argus, 10 November 1959, p 1

29. "Police Chief Blames Coloured Hooligans for Rioting at Paarl", The Cape Argus, 10 November 1959, p 1.

30. A discussion of the implications of the attacks on car owners is given below. "Police Fire in Battle with Paarl Rioters: Screaming Mob Stone Cars, Attack Occupants", The Cape Times, 10 November 1959, p 3.

31. "Police Fire in Battle with Paarl Rioters: Screaming Mob Stone Cars, Attack Occupants", The Cape Times, 10 November 1959, p 3.

32. “3 Mafekeng Children Questioned by Police”, New Age, 19 November 1959, p 3. 
minister of Native Affairs. This department was renamed Bantu Administration and Development and Verwoerd's position came to be filled by M.C. De Wet Nel in 1958. ${ }^{33}$

By 21:00 there were an estimated 4000 Coloured and African people filling the street. ${ }^{34}$ Mrs van Zyl, the owner of the Drakenstein Bazaar, watched from the windows of her shop as the crowd approached the establishment and began throwing rocks at her house next door. Some rioters attempted to break through the door with axes and iron bars. The first mention of the Paarl Police is a description of them advancing towards the demonstrators at some point after 21:00 as the Van Zyl family fled their shop and home. Those involved broke into the Van Zyl's store, as well as other shops owned by whites. ${ }^{35}$ According to the Paarl Post: "The people were going in and out of Mr Van Zyl's shop ... They carried goods ...".36 The policemen were showered with stones and bullets were fired at them from among the rioters. The rioter's shots appear to have prompted the policeman to start firing into the crowd and some participants were hit. ${ }^{37} \mathrm{Mr}$ William Bruce, a Coloured man, was severely wounded by gunshots at this time. ${ }^{38}$

By 21:30 the police had blocked off all of the streets affected by the rioting. A truck packed with policemen, armed with sten-guns and rifles, came from Cape Town and entered the Huguenot area at 23:00. ${ }^{39} \mathrm{Mr}$ William Bruce was taken to Groote Schuur hospital with a bullet wound to his head, later succumbing to his wounds. ${ }^{40} \mathrm{He}$ is the only recorded fatality. ${ }^{41}$ Ten others, including African, Coloured and white people, were taken to Paarl hospital with bullet wounds. ${ }^{42}$ A pregnant woman was shot in the stomach by police, but no further information could be found concerning her

33. The title of the article, "Verwoerd Says the British can Have All the Mafekengs", Cape Argus, 14 November 1959, also indicates that the banishment of Elizabeth Mafekeng garnered attention from the head of state. See K. Beckenridge, "Verwoerd's Bureau of Proof: Total Information in the Making of Apartheid", History Workshop Journal, 59 (2005), p 83; P. Joyce, A Concise Dictionary of South African Biography (Francolin Publishers, Cape Town, 1999), pp 275-276; Police Fire in Battle with Paarl Rioters: Screaming Mob Stone Cars, Attack Occupants", Cape Times, 10 November 1959, p 1.

34. "Police Chief Blames Coloured Hooligans for Rioting at Paarl", The Cape Argus, 10 November 1959, p 1.

35. “We Will Never Stop Saying 'Africa must come back', Elizabeth Mafekeng's Farewell Message", New Age, 12 November 1959, p 1.

36. The looting of the Van Zyl shop is as an important indication of the nature of the riots and will be discussed below. See also "5 Policemen Arrested Her: Articles Lying about in Street at Looted Shop", Paarl Post, 23 February 1959, p 3.

37. “Nie-Blanke Geweld in die Paarl: Aanrandings, Brande”, Die Burger, 10 November 1959, p 1; “Rioting Mob Smashed Cars”, Paarl Post, 10 November, 1959, p 10.

38. "3 Mafekeng Children Questioned by Police”, New Age, 19 November 1959, p 3.

39. "Nie-Blanke Geweld in die Paarl: Aanrandings, Brande"; Die Burger, 10 November 1959, p 1; "Rioting Mob Smashed Cars", Paarl Post, 10 November 1959, p 10.

40. "Police Chief Blames Coloured Hooligans for Rioting at Paarl", The Cape Argus, 10 November, 1959, p 1.

41. "Renewed Violence in Paarl", The Cape Times, 11 November 1959, p 1.

42. "Police Fire in Battle with Paarl Rioters", Cape Times, 10 November 1959, p 1. 
fate, or that of her unborn child. ${ }^{43}$ By daybreak, reinforcements in the form of three Saracens and 35 men from Cape Town were being used to patrol the streets. ${ }^{44}$

During the night and in the wake of the unrest on 9 November, 51 people were arrested, the majority of whom were Coloureds. ${ }^{45}$ Most of the newspapers analysed seemed to indicate that the state of affairs in Paarl on 10 of November was relatively peaceful. The Cape Times suggested otherwise, reporting:

Shots were fired last night on a large crowd of rioters who stoned cars and set a ransacked shop on fire as renewed violence flared up in the Paarl township of Huguenot where one man was killed and about a dozen injured on Monday night. ${ }^{46}$

It was also stated that a woman called the police on the evening of 10 November to report that there were "rioters" trying to burn her house down. After a Saracen (an armoured car), a police truck and some police vehicles moved through the area, things were quiet. ${ }^{47}$ The police issued a warning that residents of the area where unrest had initially broken out should not assemble in groups outside their homes and advised residents to stay off the street after 18:30.48

News of the events in Paarl quickly spread overseas. After the defiance campaign in 1952, which triggered discussion of South Africa's racial policies at the United Nations, and other forms of protest, the apartheid state was gaining ever more attention internationally. ${ }^{49}$ International newspapers assumed anti-apartheid rhetoric with reference to the events in Paarl, for the most part portraying participants as victims of hardening legislation; they were rallying against apartheid and in support of Mafekeng. The Daily Express ran a cover story "Riot over Exiled Mother" and both The News Chronicle and The Daily Telegraph featured articles on the cover page about events in Paarl.50 Die Burger, the South African newspaper known for its progovernment stance, saw Mrs Mafekeng and her 11 children as a "new stick with which British papers could beat South Africa". ${ }^{51}$ An extract from The People newspaper in

43. “Gesin Vlug uit Gevaargebied in Paarl”, Die Burger, 11 November 1959, p 13.

44. "Police Chief Blames Coloured Hooligans for Rioting at Paarl", The Cape Argus, 10 November 1959, p 3; “Renewed Violence in Paarl”, The Cape Times, 11 November 1959, p 1.

45. "Riot Rumours are Without Grounds: Armoured Reinforcement Cars Still Here", Paarl Post, 17 November 1959, p 1.

46. "Renewed Violence in Paarl", The Cape Times, 11 November 1959, p 1.

47. "Police Arrest 50 in Paarl Riot Area: Non-European Bars Closed", The Cape Argus, 11 November 1959, pp 1-2.

48. "Warning by Police in Paarl", The Cape Times, 12 November 1959, p 1.

49. T. Karis and G. Carter (eds), From Protest to Challenge: A Documentary History of African Politics in South Africa, 1882-1964, Volume 1 (Hoover Institution Press, Stanford, 1972), p 10.

50. “Paarl Groot Nuus in Londen”, Die Burger, 11 November 1959, p 1.

51. Translated excerpt from the original Afrikaans in, "Britse Koerante Gaan Giftig Tekere oor Mafekeng”, Die Burger, 12 November 1959, p 10. 
London clearly shows how the events on Mafekeng's banishment were to be framed and remembered:

Mrs Elizabeth Mafekeng, an African mother of 11 children and a trade union leader, has been given a week's respite before she is banished to a remote area 700 miles from her home, because it would be injurious to the good administration of Africans if she remained ... Because of her political views, a woman and a mother is to be sent into outer darkness. ${ }^{52}$

Press focus was on Mrs Mafekeng. In contrast, the police chief at Paarl, Colonel Terblanche, conveyed that he believed the cause of the riots was not Mrs Mafekeng, or a reaction to her banishment, but rather "Coloured hooligans". He said to the press on 10 November: "I am convinced the Coloured hooligans are mainly responsible for the damage and disturbances. There might have been Natives involved among the crowds, but Coloured people predominated."53 This is unsurprising because Coloured people were the most populous group in the town in 1959.54 Though Colonel Terblanche implicated "hooligans", thus discounting an organised event, ironically an excerpt from the NP newspaper, Die Burger, suggests something more planned and sinister: "Next time people have to be banished they must not be given enough time to organise [their] protests." 55 The two quotes indicate that at the time of the riots, there were discrepancies in perceptions of the causes and, significantly, the rioters themselves.

The 51 arrested had swelled to 63 by their time of their appearance in court on 13 November on charges of riotous behaviour. Of the 63,51 were Coloured people. ${ }^{56}$

52. “1000 Protest at Mother's Banishment”, Cape Times, 2 November 1959, p 1.

53. "Police Chief Blames Coloured Hooligans for Rioting at Paarl", The Cape Argus, 10 November 1959, p 1.

54. According to the 1960 census, Paarl's population comprised 14914 Whites; 24106 Coloureds; and 5483 Africans. See RSA, Population Census 6 September 1960, Volume 1, pp iii, 19.

55. Blumberg, "The Mafekeng Affair", p 46.

56. The names of the 63 who appeared in court on 13 November 1959 (excluding those whose names were crossed out on the document) were: James Andrews, Ammie Jeppe, William Festus, Johannes Lombard, Dawid Swarts, Karools Moses, Herman Groenewald, Andrew Ndili, Hendrik Heyns, Victor Pietersen, Michael Mtembu, Hassiem Davids, Sammy Pietersen, Augus Cedras, Piet Joubert, Ernest Sibeko, Hendrik Smit, Yusuf Jacobs, Cedras Fleurs, Solomon Manual, Hendrik Simmery, Abraham Borley, Reginald Ndokwana, Philemon Runelli, Stanley Hanson, Andries Hoffman, Adonis Botha, Willem Casane, Jacob Syster, Andrew Fredericks, Johannes Cupa, Pieter Odendaal, Solomon Pietersen, Daniel Pakeer, George Moses, Johnny Franke, Carstens Titus, Piet Jacobs, Johannes Syster, Johannes Parense, Pieter Lewis, John Matthews, Nicolaas Viljoen, Fritz Jordaan, Mabel Daniels, Ada Filander, Jacobus Johannes, Gert Louw, Samuel Theo, Charlie Henson, Daniel Apolis, Leonard Kortje, Guy Hauft, Jupie Arendse, Stanley Manile, Pieter de Kock, Johannes Maleke, Marthinus Fran... [ illegible]. This information was used to determine whether or not those arrested had appeared in court for other offences and/or if they were involved in political organisations. It does not appear that anyone was charged for riotous behaviour or public violence. Cape 
The group's ages varied between 24 and 61 years of age. There were two women among them. Because of a lack of evidence the case was remanded to 27 November of the same year. ${ }^{57}$ When the case continued, 80 people, 69 of whom were Coloured and 11 of whom were Africans, appeared in court. The charges of riotous behaviour were withdrawn and became charges of public violence. In Bell's South African Legal Dictionary (1951) a riot is defined as "an unlawful assembly which has actually begun to execute the purpose for which it assembled", while public violence "is committed by all such acts as openly and publicly effect, or are intended to cause, a violent and forcible disturbance of the public peace and security or a forcible invasion of the rights of other people". ${ }^{58}$ The distinction seems to be that riotous behaviour is an intentional gathering which has a specified premeditated purpose, not necessarily a violent one, and achieved that purpose. In contrast, public violence is the perpetration of violence without any other apparent motivation or objective. After the defiance campaign of 1952, the National Party government passed the Criminal Law Amendment Act which was designed to discourage "mass disobedience". Those who gathered to oppose a law "by way of protest or in support of any campaign against any law" could be sentenced to a fine of $£ 300$, three years in prison and/or ten strokes of the whip. This sentence was increased by two years or $£ 200$ if a person's actions were considered to have been intentionally encouraging others to protest. ${ }^{9}$ These laws were designed to dissuade protest/ public unrest and to indicate that those who were involved in "mass disobedience" were guaranteed to receive harsh punishment. The case concerning the events of 9 to 10 November, however, was remanded again because of lack of evidence. 60

In January of 1960, the Shoolman Hall in Lady Grey Street, Paarl, was hired for a month to resume the court case. There were rumours that it could last over two months, having the potential to be one of the longest cases in the history of the Western Cape. Most of the accused had been granted bail, although two men, thought to be members of the gangs the Elephant Kids and the Apaches, were kept in custody. ${ }^{61}$ The case resumed on 19 January and more than 500 people gathered outside the court in anticipation. ${ }^{62}$ As it progressed, it became apparent that the riots were perhaps not as organised as had been presented in some of the media.

Archives (hereafter KAB), CSC, 1/2/2/37, Paarl Magistrate Criminal Record Book, 1959-1960, Case No. 4302/13 November 1959.

57. “51 Non-Europeans in Court at Paarl on Charges of Violence”, The Cape Argus, 13 November 1959, p 1.

58. A. Milne, C. Cooper and B.D. Burne, Bell's South African Legal Dictionary (Butterworth, Durban, 1951), pp 715 and 654 respectively.

59. $\quad$ Karis and Carter (eds), From Protest to Challenge, Volume 1, pp 5-6.

60. “The Paarl Riots: 80 Appear in Court”, The Cape Argus, 27 November 1959, p 1.

61. "Riot Case in Shoolman Hall: Magistrate's Court too Small", Paarl Post, 15 January 1960, pp 1, 12.

62. “Vermis: 'n Besk. in Onlustesaak: Meer as 500 was Toeskouers", Paarl Post, 19 January 1960, p 1. 
On 29 January, Sergeant S.J. van Taak told of his experiences on the night of 9 November. His evidence was reported in the Paarl Post. "He was in a patrol lorry in Klein Drakenstein Road and saw a Coloured man near the olive trees, throw half a brick at the patrol lorry. The man was five yards away and he ran away through the olive trees." Van Taak went on to say that he then "saw a Coloured man, Gert Agulhas ... [who] threw a stone which hit him on the leg and he chased the man for a considerable distance before catching him and taking him back to the armoured car". In another incident, Van Taak witnessed four Coloured men pushing an old pillar over near the local hotel "and one of the men threw a stone at the police patrol van". The policeman "chased the man for 40 yards, catching him in front of the hotel". He ascertained that the "man's name was Sydney Jenson". Another Coloured man reportedly "threw a stone at the police van from four yards away".63

Participation was erratic with some individuals perpetrating seemingly unrelated acts of violence and vandalism. The men from the abovementioned account had scattered and none can be associated positively as protesting against the banishment of Mrs Mafekeng.

The case came to an abrupt end when on 22 February, 52 of the accused were found not guilty. The last 19 appeared in court again the next day on charges of public violence. Five were held as there were other charges, unrelated to the unrest, against them. ${ }^{64}$ Of the 19, 12 were charged with making contradictory statements. The hearing was adjourned on 23 February $1960 .{ }^{65}$ If indeed the state had garnered enough evidence to convict these participants of any organised anti-apartheid struggle, no doubt the case would have ended differently. Therefore, contemporary views and reports that the events of 9-10 November were exclusively part of organised resistance to apartheid at the banishment of Mafekeng become questionable.

There is little doubt that some groups rallied behind Mafekeng, before and during the events in Paarl, using her impressive credentials and position as a woman to oppose the apartheid state. An analysis of events specifically organised to protest her banishment further the impression of participation in the events of 9-10 November being extraordinary in comparison. On 2 November 1959, about 40 Black Sash members protested in the centre of Paarl. On the same day, almost 1000 Coloured and African people congregated in the Good Hope Hall in the town to protest the banishment of Mafekeng and passed a resolution condemning it. ${ }^{66}$ Mrs Mafekeng addressed the crowd and a woman spoke to declare that Mrs Mafekeng's only crime was trying to help those working for the canning industry by trying to improve their conditions and wages. Another asserted that increasing protest action would make it very difficult for the government to carry out the banishment. Fear of state oppression was, however, becoming appropriated by racial groups - a Coloured woman attempted

63. "Police Evidence in the Riots Trial: Sergeant Chased and Arrested Four Men", Paarl Post, 29 January 1960, p 1.

64. "Riot Case: 52 Freed", Paarl Post, 23 February 1960, p 1.

65. "Sequel to Riots Case", Paarl Post, 23 February 1960 p 5.

66. "1 000 Protest at Mother's Banishment", Cape Times, 2 November 1959, p 1. 
to encourage involvement by warning that the Coloured people might be the next to be banished from Paarl. ${ }^{67}$

Large groups amassed before the banishment was due to be enforced. Between one and two thousand people gathered outside Mrs Mafekeng's house on Friday 6 November, believing that she was to be banished on that day. ${ }^{68}$ Police were present, but there were no signs of violence. ${ }^{69}$ On Sunday 8 November between 500 and 700 people gathered in a mass meeting on the Grand Parade to protest against her banishment. ${ }^{70}$ The parliamentary representative for the African people, L.B. LeeWarden spoke at the meeting, ${ }^{71}$ and a resolution was passed requesting that Mrs Mafekeng's banishment order be withdrawn. A letter from Mafekeng, once again utilising her motherhood as a rallying point, was read:

We mothers must stand together to unite for freedom. What have I done? Even when somebody kills he has to appear in Court. How long will the people of South Africa be quiet? Today is my turn. Tomorrow it will be the turn of another mother... ${ }^{72}$

The ANC and other political organisations at the time celebrated Mafekeng as a symbol of the anti-apartheid struggle before and during the unrest in Paarl. On the night of 9 November people employed the symbols of the ANC such as the thumbs-up "Afrika!" salute of the ANC that was given or called for at various points during the riots connecting participants to the organisation. ${ }^{73}$ The salute was a gesture associated with the ANC's "Mayibuye i Afrika" which means "come back Africa". Historically, the symbolic call was accompanied by the ANC salute of a clenched fist with a thumb pointing upwards and was initially used with reference to the repossession of land. ${ }^{74}$

67. The increasing pressure being exerted by the state on racial groups in Paarl will be discussed further below. See also "1000 Protest at Mother's Banishment", Cape Times, 2 November 1959, p 1.

68. "Banished Mother May be Spirited out to avoid a Crowd", Cape Times, 9 November $1959, \mathrm{p} 1$.

69. "1000 Gather at Mafekeng Home”, Cape Times, 7 November 1959, p 1.

70. “700 Attack Ban on Mrs Mafekeng”, Cape Argus, 9 November 1959, p 5.

71. M.C. De Wet Nel was the minister of Bantu Affairs at the time. He is also referred to as Daan Nel in some sources consulted. See "Waarom Mafekeng Verban is", Paarl Post, 26 January 1960, p 1.

72. "Banished Mother May be Spirited out to Avoid a Crowd", Cape Times, 9 November 1959, p 1.

73. "Police Chief Blames Coloured Hooligans for Rioting at Paarl", The Cape Argus, 10 November 1959, p 1; “3 Mafekeng Children Questioned by Police”, New Age, 19 November 1959, p 3.

74. Raymond Suttner explains that this chant came to be associated with a call to regain land that was lost during the "wars of conquest" in the 1800s and was specifically utilised and encouraged by African leaders. See R. Suttner, "Periodisation, Cultural Construction and Representation of ANC Masculinities through Dress, Gesture and Indian Nationalist Influence", Historia, 54, 1 (May 2009), p 76. 
According to Lodge, the ANC gained support in Paarl during the 1950s in resistance to the removal of African squatters. At the time of the unrest, the African Food and Canning Workers' Union (AFCWU) was working alongside the ANC to negotiate recognition of the trade union and had made a promise not to aid the government in implementing the Group Areas Act from the Langeberg Co-operative in exchange for keeping the co-operative off the list of boycotted food companies. ${ }^{75}$ The New Age considered the trade union to be a powerful force in Paarl saying that the "fruit farmers and canning bosses ...[were] afraid of the fight the union might put up in the coming season if there [was] retrenchment and an attempt to lower wages". ${ }^{76}$ This shows that at the time of the riots the threat of retrenchments and lowering wages were curbed because of the power of the trade union - evidence of its capacity to effect organised resistance to circumstances they considered problematic.

However, although political groups were present at the protests before the riots, there were none that were clearly involved in the organisation of the events of 910 November and no leaders were clearly identifiable. Neither AFCWU leaders, other than Mrs Mafekeng, nor any others were named in any of the media accounts of 9 and 10 November. ${ }^{77}$ When people began rallying outside Mrs Mafekeng's house the FAWU website and Blumberg are the only sources to claim that political groups were present. The AFCWU was perfectly positioned to organise the riots, and although it claims on its website that it was responsible for organising the protest, there is no evidence to back this claim. ${ }^{78}$

The ANC and other political parties participated and played a role in organising the protests prior to 9-10 November, but there is not enough evidence to prove that party leadership and members actively participated in the riots themselves. The violent rhetoric of "kill them! kill them!"; "kill Verwoerd, kill De Wet Nel, kill the police!" and "keep out of the way because blood will flow tonight!" uttered during the riots of 1959 were not heard at any of the other events protesting Mrs Mafekeng's banishment. ${ }^{79}$

On close examination the violence seems almost out of place. The riots took place before Sharpeville, before the ANC and PAC were banned, and before their respective militant wings, Umkhonto we Sizwe and Poqo, were formed. The ANC only officially opened its membership to Coloured people in 1969 and as mentioned before, the majority of those participating in the riots were Coloureds. ${ }^{80}$ However, a history of

75. Lodge, “The Paarl Insurrection”, p 104.

76. "Over 80 Already in Exile”, New Age, 5 November 1959, p 3.

77. "Banished Mother May be Spirited out to Avoid a Crowd", Cape Times, 9 November 1959, p 1; “700 Attack Ban on Mrs Mafekeng”, Cape Argus, 9 November 1959, p 5.

78. "Elizabeth Mafikeng"(sic) available at http://www.fawu.org.za/index.php?include =veterans/mafikeng.html (Accessed 24 August 2015).

79. "Police Fire in Battle with Paarl Rioters: Screaming Mob Stone Cars, Attack Occupants", The Cape Times, 10 November 1959, $\mathrm{p} 1$.

80. N. Ndebele, "The African National Congress and the Policy of Non-racialism: A Study of the Membership Issue", Politikon, 29, 2 (2002), p 134. 
collaboration with Coloured farm labourers existed, especially in the Paarl region where a branch had been established by the 1920s. Peter Limb explains that Mafekeng fostered a positive perception of the ANC because of her role as a canning worker and her senior position in anti-apartheid ranks. ${ }^{81}$ De Wet Nel acknowledged that very few Africans were involved in the events of 9 to 10 November saying: "It is to the credit of the vast majority of Bantus in Paarl that they were not involved in the unrest in Paarl under the irresponsible leadership of the African National Congress." 82 This quote adds to the somewhat confusing nature of the unrest. Though there was some political affiliation between Coloured people and the ANC in Paarl, it seems odd that few Africans participated or were among the arrested, ${ }^{83}$ especially in light of involvement in the Poqo riots only three years later and the fact that Mafekeng was such an active member of the party. Although secondary literature suggests a link between the Poqo riots of 1962 and the unrest at Paarl in November 1959, no mention of PAC participation could be found. ${ }^{84}$

The portrayal of the riot is thus filled with anomalies. The majority of those involved in the riot were Coloureds and the statement by De Wet Nel indicates that the government believed that the ANC was involved, although very few Africans participated. The police chief at Paarl and others blamed the situation on what he labelled as Coloured hooligans. However, academic literature portrays the riot as a political reaction to the banishment of Mrs Mafekeng. The situation is depicted as politically charged, with thousands of people, not specifically Coloured people, formally rallying around Elizabeth Mafekeng as a political figure in a struggle against the apartheid regime. While political organisations are found to have participated actively in events before the onset of the unrest in Paarl, and some of those who were involved in the Paarl riots were seen to use ANC symbols of resistance, there was no homogenous participation from any specific political group. Instead it emerges that Coloured people made up the majority of demonstrators. Attention is now shifted to this particular group of participants.

\section{PART 2}

The Coloured people of South Africa are and were seen to inhabit a precarious part of its society in the twentieth century, especially during the apartheid era. Two commissions of inquiry were appointed to determine the position of the Coloured population in South Africa during that period. They were the Wilcocks Commission of

81. P. Limb, The ANC's Early Years: Nation, Class and Place in South Africa before 1940 (Unisa Press, Pretoria, 2010), pp 331, 429.

82. Translated from the original Afrikaans. See "Min. Nel se Verklaring oor die Onluste”, Die Burger, 13 November 1959, p 8.

83. Ndebele, "The African National Congress and the Policy of Non-racialism", p 134.

84. The "PAC rejected apartheid, but also rejected multi-racialism". It called for "government of the Africans by the Africans and for the Africans". Thus a protest characterised by Coloured participation is unlikely to be associated with the PAC. See M. Horrel, A Survey of Race Relations in South Africa, 1958-1959 (SAIRR, Johannesburg, 1960), pp 15-16. 
1937 and the Theron Commission of 1976. Both provide a glimpse into the contemporaneous ideology of the government concerning the population group and identify Coloured people as being dissatisfied with their situation in the country's society. The view is presented that Coloured people were not actively addressing that which caused their suffering, rather they seemed to be captured by resignation, perceiving themselves as powerless. However, it cannot be denied that their position was one of increasing disadvantage. The votes of the Coloured people progressively held less and less power until they were completely removed from the common voters' roll in 1956.85

Coloured people have come to be viewed largely as marginal actors in South Africa in general as well as in the struggle against the apartheid regime. ${ }^{86}$ There are various reasons for this perception. Firstly, their position in society was considered better than other "non-European" groups. The Survey of Race Relations in South Africa 1958-1959 acknowledged some Coloured political organisations, but added: "Very large numbers of Coloured people, perhaps the majority, [did] not belong to any of these organisations". There was not as urgent a need for protest among the Coloureds as other non-whites because, "the economic effects of group areas, job reservation and other proclamations [had] not yet been fully experienced by the Coloured people". ${ }^{87}$ Increasingly restrictive policies may have led to growing politicisation among Coloured people at this time. Secondly, many of the Coloured elite were considered to be positioning themselves as assimilationists. A desire to be accepted by the dominant white, middle-class society was at the forefront of certain Coloured identities as Mohamed Adhikari, a scholar of Coloured history, explains: "Throughout the twentieth century, gaining such affirmation [white acceptance] was one of the strongest imperatives within the Coloured community." 88 He writes that "... in order to distance themselves from Africans, to protect their status of relative privilege, Coloureds emphasised their partial descent from European colonists". ${ }^{89}$

Another manifestation of this aspect of Coloured identity which is seen to have caused hesitancy among some to associate with African anti-apartheid movements is that many Coloured people saw themselves, as expressed by Adhikari, "less than white: not only not black, but better than black". ${ }^{90}$ This translated into complex interactions with other non-white movements and Coloured movements were considered less radical by the South African government in comparison to other groups - which is evidenced by the fact that during the period 1960-1975, at which time the ANC and

85. Adhikari, Not White Enough Not Black Enough, p 18.

86. Adhikari, Not White Enough Not Black Enough, p 2.

87. Horrel, A Survey of Race Relations, p 17.

88. Adhikari, Not White Enough Not Black Enough, p 8.

89. M. Adhikari, "Hope, Fear, Shame, Frustration: Continuity and Change in the Expression of Coloured Identity in White Supremacist South Africa, 1910-1994," Journal of Southern African Studies, 32, 3 (September 2006), p 482.

90. Adhikari, Not White Enough Not Black Enough, p 10. 
PAC were banned, no Coloured organisations were banned. ${ }^{91}$ While some Coloured organisations and their members were involved in the run-up to the events in Paarl, there is no confirmation that supports any influence or participation from them or any other organisation in the events of 9-10 November 1959. The South African Coloured People's Organisation (SACPO) was also present at the Grand Parade meeting to protest Mafekeng's banishment. ${ }^{92}$ At this time, SACPO pursued closer connections with the Congress Alliance, which was the loose alliance orchestrated by the ANC between itself, the South African Indian Congress and the South African Congress of Trade Unions. ${ }^{93}$ Organised Coloured politics however, remained elusive on the nights of the unrest in Paarl.

Furthermore, two other events, occurring just before and after those in Paarl, suggest that the events of 9-10 November 1959 were not only an organised reaction to Mrs Mafekeng's banishment. Instead they alluded to a climate of unrest which was marked by volatility. On 7 November, a movie screening in De Doorns turned violent when too many Africans and Coloureds tried to fit into the hall where it was being shown. Approximately 400 people began throwing stones at Mr L. Rabinowitz, the organiser of the movie night, after a scene involving the checking of movie tickets by police officers coincided with someone turning the building's only light switch off. ${ }^{94}$ The second incident took place on 14 November, when unrest broke out in Wellington, a town approximately $13 \mathrm{~km}$ from Paarl. A group of about 40 Coloured men approached a garage owned by Mr Thys Maree on the outskirts of the town on that Saturday evening. They attacked Mr Maree's son and damaged property. At the time, this skirmish was thought to be related to the events in Paarl only five days earlier, although Paarl's Mayor Croucamp crassly dismissed the incident as a typical consequence of the behaviour of Coloured people over weekends. ${ }^{95}$ Formal Coloured political mobilisation was clearly limited, but the heterogeneous nature of the Cape Coloured population in the 1950s becomes an important area of enquiry with relation to those involved in the activities of 9-10 November 1959.

Pressure was being exerted on Coloured people in the wider political sphere in 1959. The national government made the headlines with an announcement that in October of that year it would allow the election of 12 Coloured representatives to the Union's Council of Coloured Affairs. There was a backlash from some in the Coloured community, highlighting schisms within Coloured politics. Previously there had only been white members appointed by the government to serve on this council but the decision was now made to incorporate Coloured members. A crowd of 200 gathered in

91. RSA, Commission of Inquiry into Matters Relating to the Coloured Population Group (E. Theron, Chairperson), (Government Printer, Pretoria, 1976), p 440.

92. Horrel, A Survey of Race Relations, p 17.

93. RSA, Commission of Inquiry into Matters Relating to the Coloured Population Group, $\mathrm{p}$ 440; Adhikari, Not White Enough Not Black Enough, p 5.

94. "Hotelbaas Vlug vir sy Lewe voor Rasende Skare Nie-Blankes", Die Burger, 12 November 1959, p 1.

95. “Klippe en Stukke Ysters Reën op Wellington: Lelike Voorval”, Paarl Post, 20 November 1959, p 6. 
the Cape Town city hall complaining that those on the council would be "a council of quislings employed to implement apartheid" and called for the Coloured men voted onto the council to be ostracised "politically, socially and personally". ${ }^{96}$ Most politically active Coloured leaders accepted by the Coloured community seem to be openly opposed to this Council. ${ }^{97}$ Only 12 Coloured men stood to fill these positions, ${ }^{98}$ and were ultimately elected by default. They were nonetheless willing to stand publically, showing marked discrepancies in political viewpoints within the Coloured community. ${ }^{99}$

In 1959, there was mounting trepidation among Coloured people in Paarl and signs of involvement in protest action. Apartheid legislation was beginning to impact upon their daily lives more acutely than before. The Group Areas Act of 1950 required people of different racial groups to live and conduct commerce in certain designated areas, ${ }^{100}$ but it seems that the authorities were slow in implementing these measures in Paarl. However, by 1959 this began to change. Coloured and white residents of Paarl were faced with being separated socially and economically. An article in the Paarl Post of 16 October 1959, just weeks before the unrest occurred, suggests that there was growing apprehension, at least the among the commercial classes in the town. Headed "Wat Omtrent Kleurling Aptekers?" (what about Coloured chemists?), it expressed concern over the implementation of the Group Areas Act because it meant that white people would no longer be able to shop for pharmaceutical products at establishments run by Coloured chemists. ${ }^{101}$ To add fuel to the rumblings of concern, on 6 November, three days before the riots, the local newspaper announced that a new separate hospital would be built for the use of "non-Europeans". ${ }^{102}$ Later in November, white residents in Paarl expressed concern over the ramifications of the act. They complained that their businesses were being threatened when they heard that a hotel would be built in the Coloured area of Paarl by a Coloured businessman and that a Coloured man had applied for a liquor license. ${ }^{103}$

It appears that in the broader, countrywide context as well as in towns such as Paarl, the situation was ripe for unrest but that events in the 1959 unrest were not characterised by homogenous Coloured mobilisation. Three dissimilar types of involvement are identified by an analysis of the riots. The first comprised those who attempted to separate themselves from the events and were "victims" in its unfolding. Gavin Lewis, in Between the Wire and the Wall, states that the majority of what he calls the "political class" were Coloureds in the upper echelons of the community,

96. “Coloured Election Boycott Pledge", Cape Times, 2 November 1959, p 3.

97. “Coloured Leaders Say Election was 'Just a Farce'”, Cape Argus, 4 November 1959, p 3.

98. “Coloured People Aloof in Election”, Cape Times, 4 November 1959, p 1.

99. RSA, Commission of Inquiry into Matters Relating to Coloured Population Group, p 34.

100. A. Mabin, "Comprehensive Segregation: The Origins of the Group Areas Act and its Planning Apparatuses", Journal of Southern African Studies, 18, 2 (June 1992), p 412.

101. "Wat Omtrent Kleurling Aptekers", Paarl Post, 16 October 1959, p 7.

102. “Aparte Hospitaal vir Nie-Blankes”, Paarl Post, 6 November 1959, p 2.

103 "Liquor License Decisions", Paarl Post, 20 November 1959, p 13. 
comprising teachers, other white-collar employees and artisans. ${ }^{104}$ The letter below, from the principal of a Coloured school in Paarl shows, to some extent, the desire to separate himself and his staff from the allegations of being complicit in the unrest. He also makes it clear that the school did not assist the police in any way.

The Editor, The Paarl Post

Much has been said about things that "took place" at our school during the recent riots, and as these false rumours are very detrimental to the name of our school, we would like to state the true facts:

At no time did we allow the rioters to enter the school building or grounds to enable the police to catch them...

The only policeman to enter the school during the riots, was Major Croucamp, who came to address the children of all three schools in the area on Wednesday, November 11. That we allowed members of the police to hide in the school, is not true - and this was proved by three members of the public whom we allowed to come and see if they could find any policemen inside ...

We also wish to bring to the notice of the public that throughout the rioting, every teacher on the staff was on duty and the attendance was excellent under the circumstances.

\section{B. Walbrugh,}

Principal 105

This letter from the school principal indicates that some Coloured people in Paarl isolated themselves from the government and from those partaking in the events. He wrote that all the staff were present at the school, and not involved in what he called "the riots", seeming to oppose the idea of involvement in the unrest, but on the other hand, he spends much of the letter attempting to convince readers that there was no collaboration between the school and the police. The fact that he deemed it necessary to write such a letter to clarify matters further encourages the conclusion that the school occupied an ambiguous space in the Paarl community in general, as well as the Coloured community within Paarl. A Cape Argus article from 1957 shows that Mr Bailey Walbrugh, the author of the letter above, was involved in a protest against the implementation of the Group Areas Act in Paarl. At this time he was the Treasurer of the Paarl Coloured Ratepayers Association. ${ }^{106}$ He was thus involved in Coloured politics and in opposition to some of the government's policies. He was thus not politically apathetic, but rather chose to be separate from the unrest on the nights of 9-10 November.

Examples of other members of the upper classes of the Paarl Coloured community who chose to separate themselves from, or avoid being victims of the events of 9 and 10 November are further evidence of the absence of their active

104. G. Lewis, Between the Wire and the Wall (David Philip, Cape Town and Johannesburg, 1987), p 251.

105. "Readers' Views: School Statement on Riots", Paarl Post, 4 December 1959, p 6.

106. "European and Coloured Objections to Paarl Zoning”, The Cape Argus, 27 September 1957, unnumbered. 
political participation in the riots. Some incidents mentioned briefly in the account of the unrest exemplify this. Mr D.J. Cupido, who was, according to the Paarl Post, well known as a leading member of the Coloured community in Paarl, was driving past and his car was showered with rocks. ${ }^{107}$ This attack on an easily recognisable member of the Coloured community indicates division in the motives of the participants as well as between members of the community. Another Coloured man, Mr G. de Vos, was beaten by the crowd. ${ }^{108}$ The participants were also divided in their approach. John Watney, a 60-year-old Coloured man, on giving a report of witnessing a car being stoned, said he feared for his life being caught in the midst of the unrest. ${ }^{109}$ One man was seen lugging away his belongings - saying that he was leaving while he still could. ${ }^{110} \mathrm{~A} \mathrm{Mr} \mathrm{A}$. Smit told the Paarl Post that a Coloured man named Mr A. Moerat warned him to get away from the crowd to ensure his safety. Mr Smit heard shouts of "Dis n Boer, slat hom!" (it's an Afrikaner/farmer, hit him") and "Witman, Afrika!" ("white man, Africa!").111 These Coloured people in and around the unrest attempted to remove themselves from the events. The last example given, of the actions of Mr Moerat, alludes to the assimilationist tendencies of Coloured political participation during apartheid as well as emphasising the divisions within the involvement of that group. The crowd's shouts were aimed at white people and the government, but its attacks were launched on Coloured members of the community too.

These incidents, along with the letter quoted, reveal disunity in political views amongst the Coloured people of Paarl; they also question the perceived purposes of those involved. The attacks carried out on Coloured members of the Paarl community by their fellow Coloureds could be indicative that some were viewed as complicit in the banishment - or it could be that the intentions of the participants were unclear. Ostensibly, those who took part were protesting against Mafekeng's banishment, but the fact that Coloured as well as white people were being attacked brings the underlying motives for involvement into question. Although the climate in Paarl was conducive to political protest, not all Coloureds in Paarl chose to participate. Instead, the evidence at hand shows that some of the Coloured "political elites" of Paarl consciously detached themselves from the events.

Elizabeth Mafekeng's cause did evoke the support of some Coloured members of the local community which led to various forms of participation. They took part in the meeting at the Good Hope Hall on 2 November where there was collaboration of different races. On that day over 1000 Coloured and African people gathered to protest against Mafekeng's banishment and a Coloured woman was one of those who addressed the crowd. ${ }^{112}$ The South African Coloured People's Organisation was one of

107. "Police Fire in Battle with Paarl Rioters: Screaming Mob Stone Cars, Attack Occupants", The Cape Times, 10 November 1959, p 3.

108. "Police Chief Blames Coloured Hooligans for Rioting at Paarl", The Cape Argus, 10 November, 1959, p 1.

109. "Rioting Mob Smashed Cars", Paarl Post, 10 November 1959, p 1.

110. "Rioting Mob Smashed Cars", Paarl Post, 10 November 1959, p 1.

111. "Rioting Mob Smashed Cars", Paarl Post, 10 November 1959, p 1.

112. “1000 Protest at Mother's Banishment”, Cape Times, 2 November 1959, p 1. 
the parties involved in the organisation of the meeting on the Grand Parade in Cape Town on 8 November, although it is unclear whether residents of Paarl were present. ${ }^{113}$ It was described as "an orderly meeting with all races loudly supporting speakers [who were] demanding that Mrs Mafekeng be allowed to stay in Paarl".114

The thousands of Coloured people involved on the nights of 9-10 November 1959 shows that there was something driving the people to congregate. ${ }^{115}$ While it appears there were some involved for the sake of Mrs Mafekeng, the analysis of the specific groups of Coloureds that participated begins to erode the idea that they all had a common cause. The Coloured woman that spoke at the Good Hope Hall on 2 November said that if Mrs Mafekeng's banishment was carried out, perhaps Coloured people could be banished next. 116 This remark expresses a fear of oppression; Coloured residents of Paarl were beginning to sense the need to oppose subjugation based on race, class and gender. They may perhaps have appropriated Mafekeng as a symbol of their own precarious position in society - as did political organisations and some members of the media. However, this remains debateable. But what does become apparent is the presence of the label "hooligans" in accounts of the riots.

A third identifiable group comprised those who were drawn to the riots for the sake of rioting, as opposed to joining because of a specific political affiliation or conviction. Of those who appeared in court on 13 November 1959, there were 32 under the age of 20 years, and five of those were 15 years or younger. Indeed there were even three 12-year-olds arrested.117 The majority of those involved in the events were young. While attempting to avoid falling into the trap of glibly labelling the group as comprising "criminals ... lower orders ... drunkards..." and in the South African case, "Coloured hooligans", the evidence shows that some consideration should be given to this possibility. ${ }^{118}$ So too should the possibility of mob dynamics during the unrest. ${ }^{119}$ In a work on the role of the mob in South African imagination, academic Lars Buur differentiates between crowd and mob: "When a crowd turns into a mob, it changes character and draws on a different set of connotations and agendas belonging to the domain of anger, uncontrolled energies, violence and, not least, excess."120

113. "Banished Mother May be Spirited out to Avoid a Crowd", Cape Times, 9 November 1959, p 1.

114. “700 Attack Ban on Mrs Mafekeng”, Cape Argus, 9 November 1959, p 5.

115. "Police Fire in Battle with Paarl Rioters: Screaming Mob Stone Cars, Attack Occupants", The Cape Times, 10 November 1959, p 1.

116. “1000 Protest at Mother's Banishment”, Cape Times, 2 November 1959, p 1.

117. KAB, CSC, 1/2/2/37, Paarl Magistrate Criminal Record Book, 1959-1960, Case 4302/ 13 November 1959.

118. G. Rudé, Paris and London in the Eighteenth Century: Studies in Popular Protest (Viking Press, New York, 1971), p 26.

119. For more information concerning mobs and riotous behaviour, see G. Le Bon, The Crowd: A Study of the Popular Mind (Batoche Books, Kitchener, 2001); Rudé, Paris and London in the Eighteenth Century; J.S. McClelland, The Crowd and the Mob: From Plato to Canett (Routledge, London, 2010).

120. L. Buur, "The Horror of the Mob: The Violence of Imagination in South Africa", Critique of Anthropology, 29, 1(2009), p 27. 
Five of those who were found not guilty of charges of public violence were nevertheless held because there were other charges against them, charges unrelated to the riots. ${ }^{121}$ It is also seen that Paarl often experienced high levels of disruptive behaviour on the weekend and in its wake. A study in the 1960 s found that $22 \%$ of the Coloured population could be classified as alcoholics, a distressingly high number that was predominantly attributed to the "tot" system of subsidising the wages of farm labourers with cheap wine, a practice especially prevalent on wine farms during the apartheid period. ${ }^{122}$ On 2 November, exactly a week before the riots, eight appeared in court for being drunk in public; six for theft; and two for assault. The week before that, on 26 October, six appeared for being drunk in public; fourteen for theft and seven for assault. Appearances in court for "disorderly behaviour" was thus not unusual and convictions were commonplace. ${ }^{123}$ Coloured people in South Africa were renowned for a high percentage of crime per capita. In 1969, no less than $27,1 \%$ of all criminal convictions in the country were Coloured people, who only constituted $13.91 \%$ of the population. ${ }^{124}$ Crime rates in Paarl were substantial too. In 1957, as many as 7523 court cases were heard in the Paarl magistrate's court.125 By 1959 this figure had increased to 12775 , of which 9732 were criminal cases. ${ }^{126}$ A more detailed analysis of criminal activity is required, but media coverage would suggest an increase during the period under investigation. This can be attributed to the general hardening of apartheid legislation at the time, when the socio-economic status of those termed "nonEuropean" declined markedly and factors precipitating in social instability were more prevalent. ${ }^{127}$

Some participants did not seem to be particularly motivated politically in their involvement. The testimony of Mabel Daniels and other members of the accused in the court case appear to support this viewpoint. She saw Saracens (armoured cars) driving past on November 10 and ran after them because she had never seen anything like them before. She stood with a group of women and children and watched.

Women in the crowd were shouting "Afrika!" and putting their thumbs up. She did so too. Mabel Daniels claimed that she "did not know it was something bad..."

Prosecutor, Mr M Smit: "You know nothing about the African National Congress?"

Mabel Daniels: "No".

121. "Riot Case: 52 Freed", Paarl Post, 23 February 1960, p 1.

122. A. Mager, "'White liquor hits black livers': Meanings of Excessive Liquor Consumption in South Africa in the Second Half of the Twentieth Century", Social Science \& Medicine, 59 (2004), p 737.

123. KAB, CSC, 1/2/2/37, Paarl Magistrate Criminal Record Book, 1959-1960, Case 3679/ 26 October 1959; and Case 4050/2 November 1959.

124. RSA, Commission of Inquiry into Matters Relating to the Coloured Population Group, $\mathrm{p}$ 263.

125. "Big Drop in Criminal Cases", Paarl Post, 21 January 1958, p 1.

126. “12,775 Court Cases”, Paarl Post, 9 February 1960, p 1.

127. RSA, Commission of Inquiry into Matters Relating to the Coloured Population Group (E. Theron, Chairman) (Government Printer, Pretoria, 1976). 
Prosecutor: "Did you tell the children to throw stones?"

Daniels: “-No."128

While Mabel Daniels could have been feigning ignorance in order to avoid prosecution on a more severe charge, this exchange in court creates the sense that there were some who were involved out of mere curiosity and excitement. Others also indicated being swept up by the crowd and being arrested despite the fact that they were simply bystanders . ${ }^{129}$ In defence of two men (referred to as Runelli and Jordaan), the defence attorney, M.S. Miller, said:

There was a general bustle and excitement and the two involved stood around and could not get out of the way fast enough ... before they knew where they were, they were taken into custody and placed into the police van. Runelli was on his way to work when he noticed the crowd and watched out of curiosity. 130

Other than those who claim to have been swept up by the crowd, some were involved in looting. One of the accused, Daniel Appoles, a 21-year-old Coloured man, was found carrying a brand new pair of shoes from the Van Zyl store. His testimony, reported in the Paarl Post, was that: "He did not go into the shop ... but went home and [on the way] picked up two pairs of new shoes which were found by the police in his home. He did not help to break into the shop". ${ }^{131}$ Once again, this testimony does not seem wholly convincing. It does however, along with the other testimonies, contribute to the idea of haphazard involvement in and contribution to the unrest as well as hooliganism and opportunistic theft and destruction of property. This is further entrenched by the looting of the well-liked Van Zyl shop. According to undisclosed informants to the New Age:

The people had no quarrel with the Van Zyls. Mr Van Zyl was always good to us, and Mrs Van Zyl was the dressmaker to half the neighbourhood. Elizabeth Mafekeng herself had been a customer of Mrs Van Zyl and had only recently paid her $£ 9$ for clothing for her family. Why should we attack these people? ${ }^{132}$

Furthermore, the courts could not find any evidence to secure a conviction of politically motivated behaviour. If indeed the unrest was concerned only and obviously with Mafekeng's banishment; the anti-apartheid struggle and other politically subversive motivations, then the charge would have been a necessity. As referred to already, changing the charge to public violence is also revealing. Of the approximately 80 people arrested for inciting riotous behaviour, none were convicted for their involvement in the events of 9 to 10 November, ${ }^{133}$ only twelve appeared in court on 23

128. “Woman's Version of the Riots”, Paarl Post, 23 February 1960, p 5.

129. “51 Persone verskyn in die hof”, Paarl Post, 20 November 1959, p 2.

130. Own translation from the original Afrikaans, "51 Persone Verskyn in die Hof", Paarl Post, 20 November 1959, p 2.

131. "5 Policemen Arrested Her: Articles Lying about in Street at Looted Shop", Paarl Post, 23 February 1959, p 3.

132. “3 Mafekeng Children Questioned by Police”, New Age, 19 November 1959, p 3.

133. "Riot Case: 52 Freed", Paarl Post, 23 February 1960, p 1. 
February 1960, and they were charged with making contradictory statements. ${ }^{134}$ Indeed $80 \%$ of those arrested were acquitted. While the participation of these people in the unrest was not viewed as serious enough to convict them, it also does not seem to have caused undue concern in government circles. The parliamentary debates of 1960 referred to the details of the banishment of Elizabeth Mafekeng and the fact that the order garnered national and international attention, but no mention is made of the events in Paarl.135 Given the details of the unrest; the examination of those involved and the reactions to the participants by the court and the state, it seems that the events of 9-10 November being positioned around a central figure of the anti-apartheid struggle has caused the neglect of the examination of those involved and the clues they give concerning the nature of discontent and protest at this point during apartheid.

\section{Conclusion}

The Paarl riots of 9-10 November 1959 appear to be represented in secondary literature as planned, politically charged events where thousands united to protest against the banishment of Elizabeth Mafekeng and ultimately, apartheid. Some see this outburst as the first significant reaction to apartheid in the Western Cape. However, closer examination of the riots begins to erode the view that they unfolded merely as an organised reaction to the banishment of Mafekeng and in a show of dissatisfaction against the apartheid state. It is contended that there were other intricacies and nuances to involvement in the unrest. While Elizabeth Mafekeng was an inspirational figure and various political organisations rallied in her support, the events of 9-10 November 1959 appear to be different to those that were held to protest her banishment. Political groups including the ANC and other members of the Congress Alliance participated in events prior to those in Paarl of November 1959, but official participation in this particular outburst could not be established. Instead it is concluded that the majority of the rioters were Coloured people and these participants can be categorised loosely into three groups. There were certainly individual motivations, but these groups were clearly identifiable.

Firstly, the members of the Coloured upper class in Paarl were generally politically active, but attempted to separate themselves from the events of 9-10 November; where they suffered at the hands of the participants in the riots. Secondly, there were some residents who participated actively on behalf of Mrs Mafekeng. They were those who assembled outside Mrs Mafekeng's house and engaged in the organised protests before the banishment. The third group comprises those who participated incidentally, or even "accidentally". They were not motivated to take part as a show of political support for a cause. The majority of people in the crowd on the nights of the riots were part of this group. Evidence of their apolitical involvement is found in the outcome of the court case and the state's lack of reaction to the disturbances in Paarl.

134. "Sequel to Riots Case", Paarl Post, 23 February 1960, p 5.

135. Unie van Suid Afrika, Volksraad Debatte, Deel 103-105 (Hansard), 15 Januarie-4 Maart 1960, pp 187-188, cols 274-275. 
It cannot be ignored that Elizabeth Mafekeng triggered the organisation of events prior to those of 9-10 November 1959, and that politicised activity took place on those nights in Paarl, although a closer look at the involvement of Coloured people shows that many were not rallying around her cause, nor were they formally mobilised politically. Perhaps in the rush to attest this riot to a worthy purpose, the finer details of the events, such as Coloured participation, have been masked in the context of contemporary anti-apartheid myth making.

\section{REFERENCES}

Adhikari, M., "Hope, Fear, Shame, Frustration: Continuity and Change in the Expression of Coloured Identity in White Supremacist South Africa, 1910-1994", Journal of Southern African Studies, 32, 3 (September 2006).

Adhikari, M., Not White Enough Not Black Enough (Double Storey Books, Cape Town, 2005).

Badat, S., The Forgotten People: Political Banishment under Apartheid (Jacana Media, Johannesburg, 2012).

Beckenridge, K., "Verwoerd's Bureau of Proof: Total Information in the Making of Apartheid", History Workshop Journal, 59 (2005).

Buur, L., "The Horror of the Mob: The Violence of Imagination in South Africa", Critique of Anthropology, 29, 1 (2009).

"Elizabeth Mafikeng" online at http://www.fawu.org.za/index.php?include=veterans/ mafikeng.html (1 July 2015).

Fransch, C.J.P., "We would have no name': The Porosity of Locational and Racial Identities amongst the Coloured Communities of Stellenbosch, c. 1890-1960s", African Studies, 69, 3 (December 2010).

Gurney, C., '“A great cause': The Origins of the Anti-Apartheid Movement, June 1959March 1960", Journal of Southern African Studies, 26, 1 (March 2000).

Horrel, M. (compiler), A Survey of Race Relations in South Africa, 1958-1959 (South African Institute of Race Relations, Johannesburg, 1960).

Human Sciences Research Council, Women Marching into the 21st Century: Wathint' Abafazi, Wathint' Imbokodo (HSRC, Cape Town, 2000).

Joyce, P., A Concise Dictionary of South African Biography (Francolin Publishers, Cape Town, 1999)

Karis, T. and Carter, G. (eds), From Protest to Challenge: A Documentary History of African Politics in South Africa, 1882-1964, Volume 1 (Hoover Institution Press, Stanford, 1972).

Karis, T., and Gerhart, G.M. (eds), From Protest to Challenge: A Documentary History of African Politics in South Africa, 1882-1964, Volume 3, Challenge and Violence, 1953 -1964 (Hoover Institution Press, Stanford, 1977).

Le Bon, G., The Crowd: A Study of the Popular Mind (Batoche Books, Kitchener, 2001).

Lewis, G., Between the Wire and the Wall (David Philip, Cape Town and Johannesburg, 1987).

Lodge, T., "The Paarl Insurrection: A South African Uprising”, African Studies Review, 25, 4 (December 1982). 
Limb, P., The ANC's Early Years: Nation, Class and Place in South Africa before 1940 (Unisa Press, Pretoria, 2010).

Mabin, A., "Comprehensive Segregation: The Origins of the Group Areas Act and its Planning Apparatuses", Journal of Southern African Studies, 18, 2 (Junie 1992).

Mager, A., "'White liquor hits black livers': Meanings of Excessive Liquor Consumption in South Africa in the Second Half of the Twentieth Century", Social Science \& Medicine, 59 (2004).

McClelland, J.S., The Crowd and the Mob: From Plato to Canett (Routledge, London, 2010).

Milne, A., Cooper, C. and Burne, B.D., Bell's South African Legal Dictionary (Butterworth, Durban, 1951).

Ndebele, N., "The African National Congress and the Policy of Non-racialism: A Study of the Membership Issue", Politikon, 29, 2 (2002).

Nix, J., Freedom of Expression Institute, "Action against journalists in South Africa between 1960 and 1993", May 1997 at http://www.fxi.org.za/old\% 20webpages/archives/DUMP/text\%20files/detentio.txt (Accessed 8 October 2015).

Republic of South Africa, Bureau of Statistics, Population Census, Volume 1, 6 September 1960, Geographical Distribution of the Population (Government Printer, Pretoria 1961).

Republic of South Africa, Commission Appointed to Inquire into the Events on 20-22 November 1962 at Paarl, and the Causes Which Gave Rise Thereto (Government Printer, Pretoria, 1963).

Republic of South Africa, Commission of Inquiry into Matters Relating to the Coloured Population Group (Government Printer, Pretoria, 1976).

Republic of South Africa, Native Administration Act of 1927: http://uir.unisa.ac.za/ bitstream/handle/10500/6648/ZKM C3 69.pdf?sequence=1(Accessed 5 August 2015).

Rudé, G., Paris and London in the Eighteenth Century: Studies in Popular Protest (Viking Press, New York, 1971).

Shaw, G., The Cape Times: An Informal History (New Africa Books, Cape Town, 1999).

Suttner, R., "Periodisation, Cultural Construction and Representation of ANC Masculinities through Dress, Gesture and Indian Nationalist Influence", Historia, 54, 1 (May 2009).

Suttner, R., The ANC Underground in South Africa, 1950-1976 (First Forum Press, Online USA, 2009).

Union of South Africa, Report of the Commission of Inquiry Regarding the Cape Coloured Population of the Union (Government Printer, Pretoria, 1937).

Unie van Suid-Afrika, Volksraad Debatte, Deel 103-105 (Hansard), 15 January-4 March 1960 (Nasionale Handelsdrukkery, Elsiesrivier, 1960).

Van Laun, B., "In the Shadows of the Archives: Investigating the Paarl March of 22 November 1962", MA dissertation, University of the Western Cape, 2012. 